\title{
Role of chloroplast retention in a marine dinoflagellate
}

\author{
Alf Skovgaard* \\ Marine Biological Laboratory, University of Copenhagen, Strandpromenaden 5, DK-3000 Helsingør, Denmark
}

\begin{abstract}
The dinoflagellate Gymnodinium 'gracilentum' feeds on the cryptophyte Rhodomonas salina and retains the chloroplasts of the prey as functional kleptochloroplasts. Using kleptochloroplasts, G. 'gracilentum' becomes a mixotroph, acquiring a proportion of its organic carbon demand through photosynthesis, but the kleptochloroplasts and their photosynthetic activity are lost within a few days. Photosynthesis seems, primarily, to be an important means of nutrition for $G$. 'gracilentum' during food depletion, thereby enhancing the survival of the species during food limitation and starvation. However, light has a positive effect on growth kinetics of $G$. 'gracilentum' in food replete cultures: growth and ingestion rates are higher at a high light intensity than at a low light intensity. This effect may be due to other factors than photosynthetic activity of kleptochloroplasts, since a control experiment with a supposed strictly heterotrophic dinoflagellate, Gymnodinium sp., also showed a dependence of growth kinetics on light intensity.
\end{abstract}

KEY WORDS: Gymnodinium - Dinoflagellate $\cdot$ Chloroplast retention - Cryptophyte Mixotrophy Heterotrophy

\section{INTRODUCTION}

A number of dinoflagellate species which lack chloroplasts of their own are known to host chloroplasts retained from cryptophyte prey. Such kleptochloroplasts (Schnepf \& Elbrächter 1992) have been found in Amphidinium poecilochroum (Larsen 1988), Gymnodinium acidotum (Fields \& Rhodes 1991), A. latum (Horiguchi \& Pienaar 1992), and most recently in Pfiesteria piscicida (Lewitus et al. pers. comm.). Ultrastructural studies have likewise revealed that $A$. wigrense (Wilcox \& Wedemayer 1985), G. aeruginosum (Schnepf et al. 1989) and Dinophysis spp. (Schnepf \& Elbrächter 1988 ) contain cryptophyte-like chloroplasts. However, whether these originate from ingested prey or constitute permanent endosymbionts has not yet been established. Schnepf et al. (1989) implied that the chloroplasts of $G$. aeruginosum were most likely obtained through chloroplast retention. This is indeed plausible, considering that Popovský \& Pfiester (1990) believed $G$. aeruginosum and $G$. acidotum to be conspecific. As dis-

·E-mail:alfmbl@vip.cybercity.dk cussed by Schnepf \& Elbrächter (1992), it is doubtful that $A$. wigrense has genuine chloroplasts, since the species was originally described as being colourless. Also Paulsenella spp. might utilize kleptochloroplasts: these species are predators on diatoms and, due to the appearance of the chloroplasts following ingestion, Schnepf et al. (1988) suggested that these remained photosynthetically active for some time.

Chloroplast-retaining dinoflagellates at times play major roles in aquatic ecosystems (Burkholder \& Glasgow 1995, Burkholder et al. 1995). However, surprisingly little is known about their ecology and, especially, about their nutrition and the importance of photosynthesis of the kleptochloroplasts for their survival and growth. In most cases it is unknown for how long the chloroplasts are retained and whether they are actually photosynthetically active. Fields \& Rhodes (1991) showed that pigmented Gymnodinium acidotum cells underwent cell divisions for up to $10 \mathrm{~d}$ in monocultures and these remained viable for more than $15 \mathrm{~d}$, but after 13 to $14 \mathrm{~d}$ the cells had lost the chloroplasts. Recently, Lewitus et al. (pers. comm.) using microautoradiography showed that the kleptochloro- 
plasts in Pfiesteria piscicida are photosynthetically active, and the authors suggested that photosynthesis is an important mechanism of survival during periods of low prey availability.

The present work describes the nutrition of a gymnodinoid, plastid-retaining dinoflagellate and represents the first attempt to quantify the relative importance of phagotrophy and kleptochloroplast photosynthesis for such an organism, thus gaining information on the autecology and trophic position of a dinoflagellate representative of this specialized mode of nutrition. The plastid-retaining dinoflagellate used in this study is believed to be identical to Gymnodinium gracilentum (Campbell 1973). However, since the description of this species has not yet been validly published, it will be referred to as $G$. 'gracilentum'. The findings are compared with those for another Gymnodinium species which is supposed to be strictly heterotrophic.

\section{MATERIALS AND METHODS}

Gymnodinium 'gracilentum' was isolated by $\mathrm{H}$. $\mathrm{H}$. Jakobsen from an unfiltered surface water sample from Øresund off the coast of Helsingør, Denmark, in July 1996. Gymnodinium sp. was originally isolated by Jakobsen \& Hansen (1997). The dinoflagellates were cultivated in B-medium (Hansen 1989) based on autoclaved, $0.2 \mu \mathrm{m}$ filtered seawater (salinity $=30 \%$ ) with the cryptophyte Rhodomonas salina as prey. $R$. salina was obtained from the culture collection of the Marine Biological Laboratory, Helsingør. Stock cultures were kept in polystyrene bottles mounted on a plankton wheel ( $1 \mathrm{rpm}$ ) at $\sim 15^{\circ} \mathrm{C}$ in dim light ( 5 to $15 \mu \mathrm{E} \mathrm{m} \mathrm{m}^{-2} \mathrm{~s}^{-1}$, cool white fluorescent tubes). Experiments were carried out in $62 \mathrm{ml}$ polystyrene culture tissue bottles mounted on a vertically rotating wheel $(1 \mathrm{rpm})$ which was kept in a water-cooled incubator and exposed to a day:night cycle of 16:8 h light:dark. Photosynthetically active radiation (400 to $700 \mathrm{~nm}$ ) was measured outside the culture bottles with a LI-COR LI-1000 data logger connected to a spherical LI-193SA underwater radiation sensor (LI-COR Inc., NE, USA). The temperature was monitored in 10 min intervals with an EBI data logger system (EBRO Electronics $\mathrm{GmbH}$, Germany) and kept within the range of $15.5^{\circ} \mathrm{C}$ (dark period) to $16.5^{\circ} \mathrm{C}$ (light period). Experiments were carried out for both dinoflagellate species in order to quantify survival (or growth) in the light and in the dark during starvation, ability to fix inorganic carbon by photosynthesis, and growth and ingestion rates at low and high light intensities in food replete cultures.

Survival during starvation. Cultures of both dinoflagellate species were kept in $270 \mathrm{ml}$ bottles at $90 \mu \mathrm{E} \mathrm{m} \mathrm{m}^{-2}$ $\mathrm{s}^{-1}$ for 3 to 4 d until all prey organisms had disappeared from the cultures. Each culture was then split into 6 aliquots which were transferred to $62 \mathrm{ml}$ bottles and these were filled with media. 3 replicates were kept in the light and 3 in darkness (wrapped in aluminum foil). Samples were taken periodically for 4 to $6 \mathrm{~d}$ by fixing $1 \mathrm{ml}$ of each culture directly into a $1 \mathrm{ml}$ SedgewickRafter chamber containing $8 \mu$ l of $25 \%$ glutaraldehyde. The final concentration of $2 \%$ glutaraldehyde resulted in a fixation with a minimum of distortion. At least 400 cells were counted per sample using a Nikon Diaphot microscope. Cell volumes were estimated from linear dimensions (length and width) assuming the shape of a prolate ellipsoid and volumes were converted to carbon content according to the regression given by Strathmann (1967). All cell measurements were made within 30 min after fixation by using an ocular micrometer at $\times 400$ ( $\geq 20$ cells measured per replicate). Since starving heterotrophic flagellates are able to undergo divisions without any increase in biomass (Fenchel 1982b), population sizes were expressed as total biovolumes, i.e. cell numbers multiplied by mean cell volumes.

Photosynthesis. To determine the ${ }^{14} \mathrm{C}$ incorporation rates, 4 replicate $23 \mathrm{ml}$ glass scintillation vials were filled with $>2$ d acclimated Gymnodinium spp. culture. In addition 4 dark controls were set up. $\mathrm{A} \mathrm{NaH}^{14} \mathrm{CO}_{3}$ stock solution (specific activity $=100 \mu \mathrm{Ci} \mathrm{m} l^{-1}$, Carbon 14 Centralen, Denmark) was added, resulting in a specific activity of $\sim 0.5 \mu \mathrm{Ci} \mathrm{m} l^{-1}$. The vials were incubated for $3 \mathrm{~h}$ at $90 \mu \mathrm{E} \mathrm{m} \mathrm{m}^{-2} \mathrm{~s}^{-1}$ (incorporation of ${ }^{14} \mathrm{C}$ was linear with time for at least $4 \mathrm{~h}$, data not shown) whereupon $8 \mathrm{ml}$ from each vial was transferred to new scintillation vials and excess $\mathrm{H}^{14} \mathrm{CO}_{3}{ }^{-}$was removed by diffusion for $24 \mathrm{~h}$ after the addition of $100 \mu \mathrm{l}$ of $1 \mathrm{M} \mathrm{HCl}$. Total activities were determined in $100 \mu$ l of sample to which $200 \mu l$ phenylethylamine was added. To count radioactivity, $10 \mathrm{ml}$ of Packard Insta-Gel scintillation cocktail was added and activity determined with a Packard 1500 Tri-Carb liquid scintillation analyzer with quench correction by external standards. Photosynthetic rates, $P$. were calculated following the equation given by Parsons et al. (1984). The photosynthesis experiment was carried out for Gymnodinium 'gracilentum' cultures which were food limited but not starved, i.e. Rhodomonas salina was still present, but in low number. The predator:prey concentration ratio was approx. 10:1 ${ }^{14} \mathrm{C}$ incorporation of $G$. 'gracilentum' was determined as total incorporation minus the estimated prey contribution, as determined in control incubations containing $R$ salina only. This experiment was also performed at $6 \mu \mathrm{E} \mathrm{m}^{-2} \mathrm{~s}^{-1}$ In addition, experiments were made with $G$. 'gracilentum' cultures which had been starved for approx. 12 and 48 h, i.e. no prey was left. Finally, an experiment was performed with Gymno- 
dinium sp. cultures which had been starved for approx. $48 \mathrm{~h}$.

Growth and ingestion rates. Dinoflagellate and prey cultures were acclimated to either low light $\left(6 \mu \mathrm{E} \mathrm{m}^{-2}\right.$

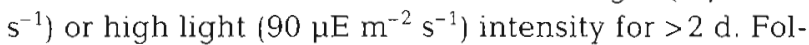
lowing acclimation, 3 replicate cultures of predator with prey were set up (initial concentrations $\sim 200$ to $600 \mathrm{ml}^{-1}$ and $\sim 4000$ to $7000 \mathrm{ml}^{-1}$, respectively) plus 3 replicate control cultures of prey only (initial concentration $\sim 1000$ to $3000 \mathrm{ml}^{-1}$ ). These cultures were thereafter incubated for $4 \mathrm{~d}$. Samples were taken every 12 to $24 \mathrm{~h}$ and treated as described above. Data for calculation of growth and ingestion rates were obtained only from the part of the incubations where the prey cell concentrations were $>4000$ cells $\mathrm{ml}^{-1}$, which is well above the saturation limit for Gymnodinium sp. (1300 Rhodomonas salina cells $\mathrm{ml}^{-1}$; Jakobsen \& Hansen 1997). Growth rates, $\mu$ (dimension: $\mathrm{d}^{-1}$ ), were determined assuming exponential growth, taking changes in cell volume into account, i.e.

$$
\mu=\frac{1}{t}\left(\ln \frac{N_{t} V_{o I_{t}}}{V_{0} I_{0}}-\ln N_{0}\right)
$$

where $N_{0}$ and $N_{t}$ denote the cell concentrations and $\mathrm{Vol}_{0}$ and $\mathrm{Vol}_{t}$ the mean cell volume at the beginning and at the end of the incubation period $(t)$, respectively.

Per capita ingestion rates, $U$ (prey $\mathrm{d}^{-1}$ ), were calculated on the basis of decrease in prey concentrations as compared with the controls using the equations given previously (Skovgaard 1996; see also Marin et al. 1986, Hansen \& Nielsen 1997). Gross growth efficiency, GGE, was determined as increment of predator carbon per ingested amount of prey carbon. Thus (derived from Fenchel 1982a):

$$
G G E=\frac{\mu C_{\text {pred }}}{U C_{\text {prey }}}
$$

where $C_{\text {pred }}$ and $C_{\text {prey }}$ denote the estimated carbon content of the predator and the prey, respectively (pg $\mathrm{C} \mathrm{cell}{ }^{-1}$ ). The mean prey volume was $265 \mu^{3}$ (based on $>300$ cells measured at both light intensi-

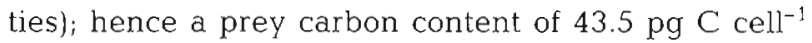
(Strathmann 1967) was used for all GGE calculations. It is important to note that Eq. (2) relates to strictly heterotrophic organisms only. However, one may hypothesize that by calculating GGE for a mixotrophic organism, it can be revealed whether phagotrophic carbon uptake is substantially supplemented by photosynthesis, since this is likely to result in an erroneously high GGE estimate

Light microscopy. Pictures were taken of live cells using Zeiss Axiophot and Olympus BH-2 microscopes, both equipped with differential interference contrast light and $a \times 100$ oil emulsion objective.

\section{RESULTS}

\section{Cell morphology}

Cells of Gymnodinium 'gracilentum' measure approx. $14 \times 8 \mu \mathrm{m}$ when grown in the presence of Rhodomonas salina. Under these conditions each dinoflagellate cell contains several reddish chloroplasts (Fig. 1a, b) and individuais are frequently seen swimming with a $R$. salina cell attached to their sulcal area while feeding. In the absence of prey, chloroplasts decrease in numbers (Fig. 1c-f) and the cells will therefore eventually become colourless and their size will reduce to approx. $11 \times 5 \mu \mathrm{m}$ (Fig. 1f). After 4 to $5 \mathrm{~d}$ of starvation, most cells have lost their colouration. If food is then added, feeding will quickly commence and the dinoflagellates soon regain their original size and colouration. This will happen even after more than a week of starvation. In plastidic G. 'gracilentum' cells the chloroplasts appear 'healthy', i.e. they possess visible chloroplast lamellae (Fig. 1a, b) and show a colour resembling that of $R$. salina. Superficially, each dinoflagellate cell seems to contain up to $4-8$ kleptochloroplasts (Fig. 1a, b). However, considering that the prey chloroplasts are two-lobed (Fig. 1h), it is more likely that the cells each contain 2 to 4 two-lobed chloroplasts. In fact, chloroplasts are often located 'in pairs' in G. 'gracilentum' (Fig. 1a-d). In addition to kleptochloroplasts, $G$. 'gracilentum' often contains amorphous food vacuoles in the posterior part of the cell (Fig. 1c, d), possibly representing digestive vacuoles. Starvation of the dinoflagellate is accompanied by a change in cell shape: the episoma becomes pointed in starved cells (Fig. 1f) versus rounded in well-fed cells (Fig. 1a, b). Feeding in G. 'gracilentum' involves a feeding tube emerging from the sulcus, and the predator is thus able to ingest prey of a size comparable to its own.

The heterotrophic dinoflagellate Gymnodinium sp. (Fig. 1g; Jakobsen \& Hansen 1997) is slightly smaller than $G$. 'gracilentum', measuring 6 to $11 \times 4$ to $8 \mu \mathrm{m}$, depending on the nutritional state of the cells. The species seems to feed by direct engulfment and its food vacuoles appear rounded and amorphous without any lamellar structure (Fig. 1g; Jakobsen \& Hansen 1997).

\section{Survival during starvation}

Light had a positive influence on the biomass of Gymnodinium 'gracilentum' during starvation. During the first 2 to $3 \mathrm{~d}$ following the onset of starvation, cell division in G. 'gracilentum' cultures kept in the light continued for about 1 division per cell (Fig. 2a). In the dark, fewer cell divisions occurred and only within the 
first day. The cell divisions in the dark, however, do not represent any growth in biomass since mean cell volume was reduced drastically during this period (Fig. 2b). The total biovolume of $G$. 'gracilentum' thus decreased exponentially in the dark (Fig. 3), and after $6 \mathrm{~d}$ of incubation without food, total biovolume had
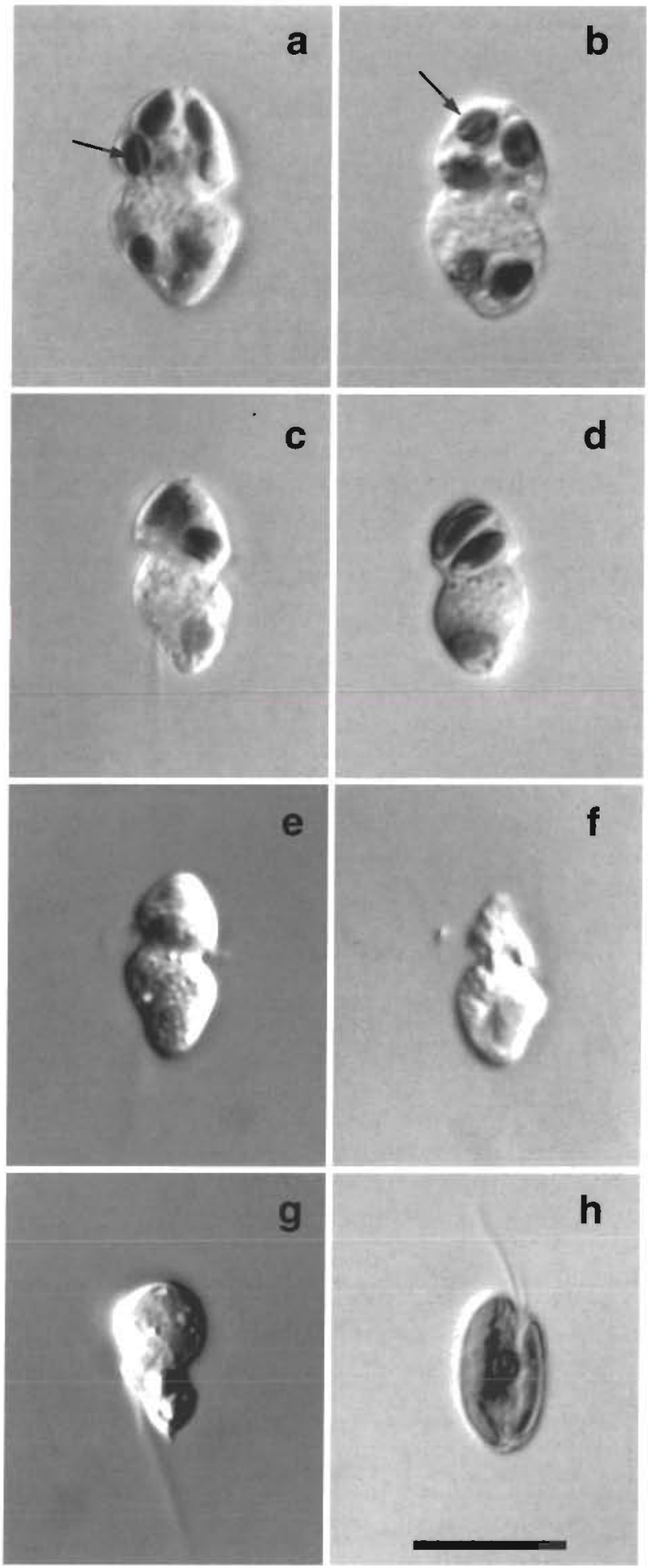

decreased by approx. $60 \%$. In the light, in contrast, the reduction in cell volume was less pronounced and $G$. 'gracilentum' exhibited growth in total biovolume for at least the first $1.5 \mathrm{~d}$ of starvation. After $3 \mathrm{~d}$, total biovolume in the light equaled the Day 0 values and after $6 \mathrm{~d}$ it had only decreased slightly.

The influence of light on the biomass of Gymnodinium sp. during starvation was less pronounced: cell concentration and cell volume were almost similar in light and in the dark for this species (Fig. 4). However, changes in total biovolume show that the species did exhibit some growth during the first $1.5 \mathrm{~d}$ of starvation in the light whereas no growth was observed in the dark (Fig. 5). After $4 \mathrm{~d}$, total biovolume in both the light and the dark treatments had decreased by approx. $70 \%$.

\section{Photosynthesis}

In cultures which were food limited but not yet fully deprived of food, Gymnodinium 'gracilentum' had photosynthetic carbon fixation rates of 123 and 3 pg $C$ cell ${ }^{-1} \mathrm{~d}^{-1}$ at the light intensities of 90 and $6 \mu \mathrm{E} \mathrm{m} \mathrm{m}^{-2} \mathrm{~s}^{-1}$. respectively (Table 1), which correspond to daily photosynthetic rates of 187 and $5 \%$ of its own cell carbon content. G. 'gracilentum' cells which had been

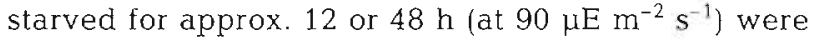
capable of fixing only 81 and $3 \%$ of their cell carbon content $\mathrm{d}^{-1}$, respectively. Incorporation of inorganic carbon by Gymnodinium sp. was similar in the light and in dark controls, i.e. no measurable photosynthesis occurred. Rhodomonas salina had carbon fixation rates of 439 and $17 \%$ its own cell carbon content $d^{-1}$ at 90

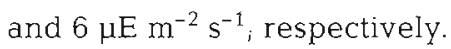

\section{Growth and ingestion rates}

The development in cell concentrations is shown in Fig. 6. The predators exhibited exponential growth

Fig. 1. Light micrographs of live cells. (a-f) Gymnodinium 'gracilentum'. (a, b) Well-fed cells with each several chloroplasts. The chloroplast ultrastructure seems intact (arrows). (c, d) Starved cells which have reduced their size and lost all but 2 chloroplasts. The vacuoles in the posterior end of the cells appear to be digestive vacuoles. (e) Following 2 to $3 \mathrm{~d}$ of starvation: cell size has been further reduced and the cell has only 1 chloroplast left. (f) Long-term (approx 1 wk) starved. cell with all chloroplasts eliminated. The cell size is greatly reduced and the episoma has become pointed. (g) Gymnodinium sp.; remnants of food vacuoles are visible. (h) Rhodomonas salina with two-lobed chloroplast and a central pyrenoid

Scale bar $=10 \mu \mathrm{m}$, all figures of same magnification 


\section{Gymnodinium 'gracilentum'}

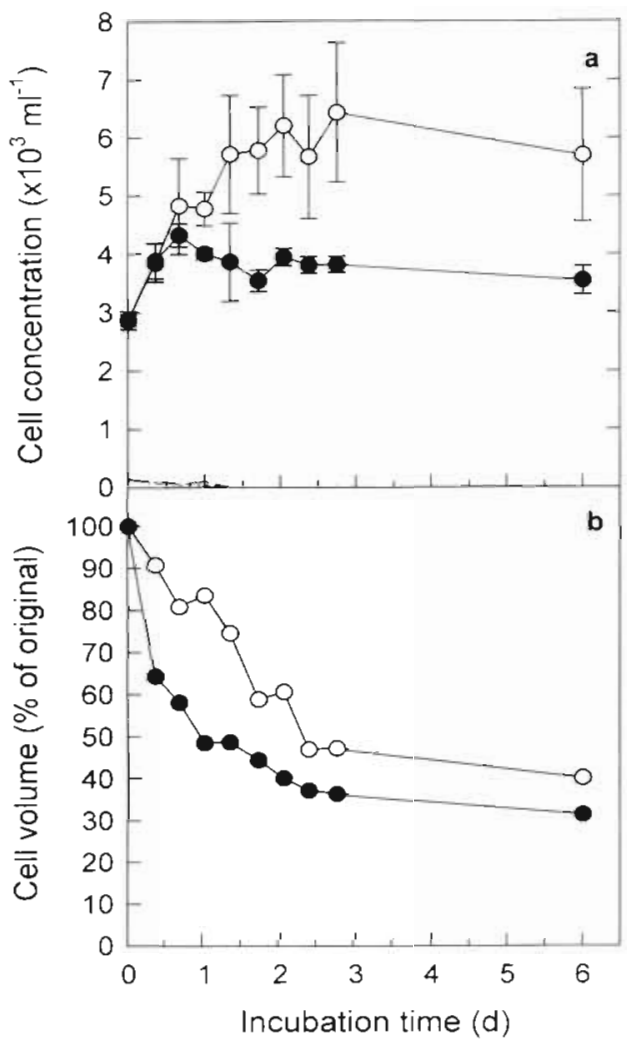

Fig. 2. Development in (a) cell concentrations and (b) mean cell volume of Gymnodinium 'gracilentum' in starved cultures in light $\left(90 \mathrm{\mu E} \mathrm{m}^{-2} \mathrm{~s}^{-1}\right)(0)$ and in darkness (0). Dashed and dotted lines show residual prey concentrations. Symbols represent means of triplicate incubations \pm SE

\section{Gymnodinium 'gracilentum'}

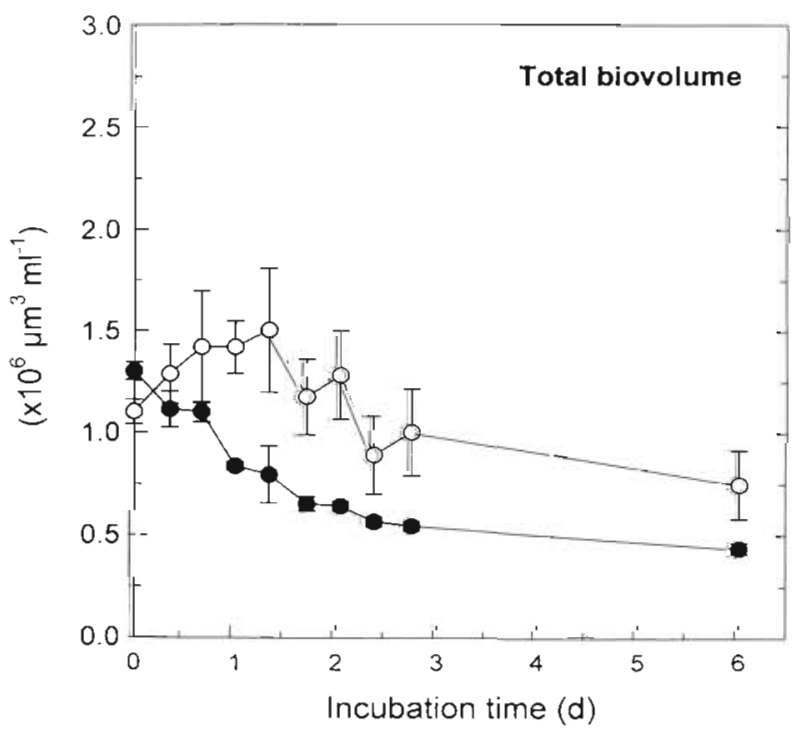

Fig. 3. Development in total biovolume of starved Gymnodinium 'gracilentum' populations in triplicate cultures in light and in darkness. Data from Fig, 2, symbols as in Fig. 2

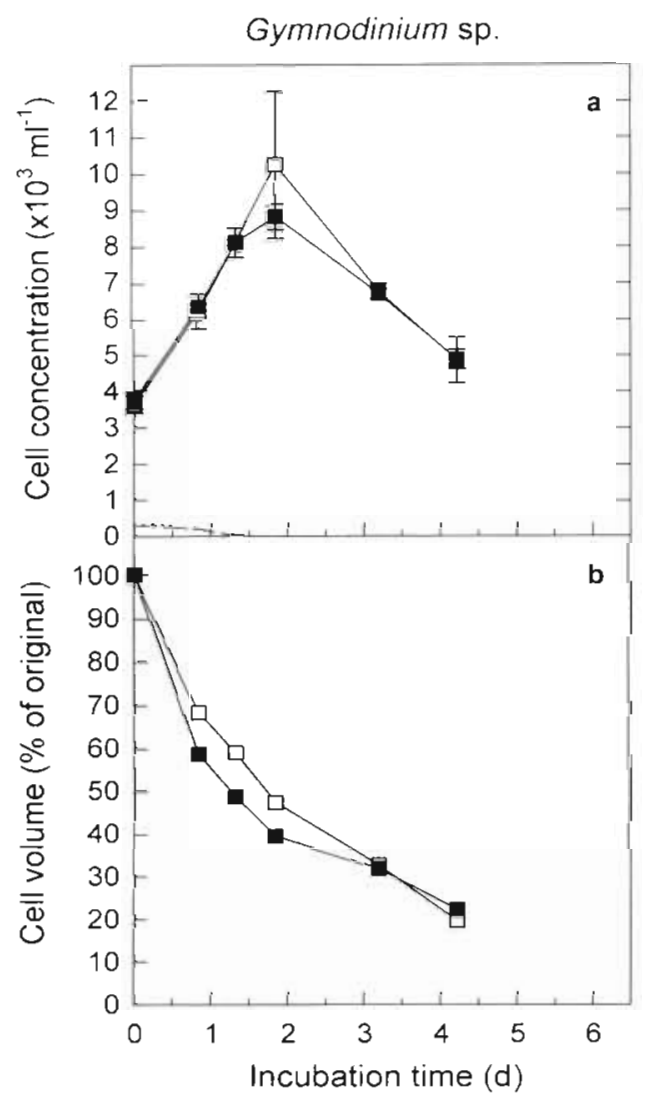

Fig. 4. Development in (a) cell concentrations and (b) mean cell volume of Gymnodinium sp. in starved cultures in light $\left(90 \mu \mathrm{E} \mathrm{m}^{-2} \mathrm{~s}^{-1}\right)$ ( $\square$ ) and in darkness (ם). Dashed and dotted lines show residual prey concentrations. Symbols represent means of triplicate incubations $\pm \mathrm{SE}$

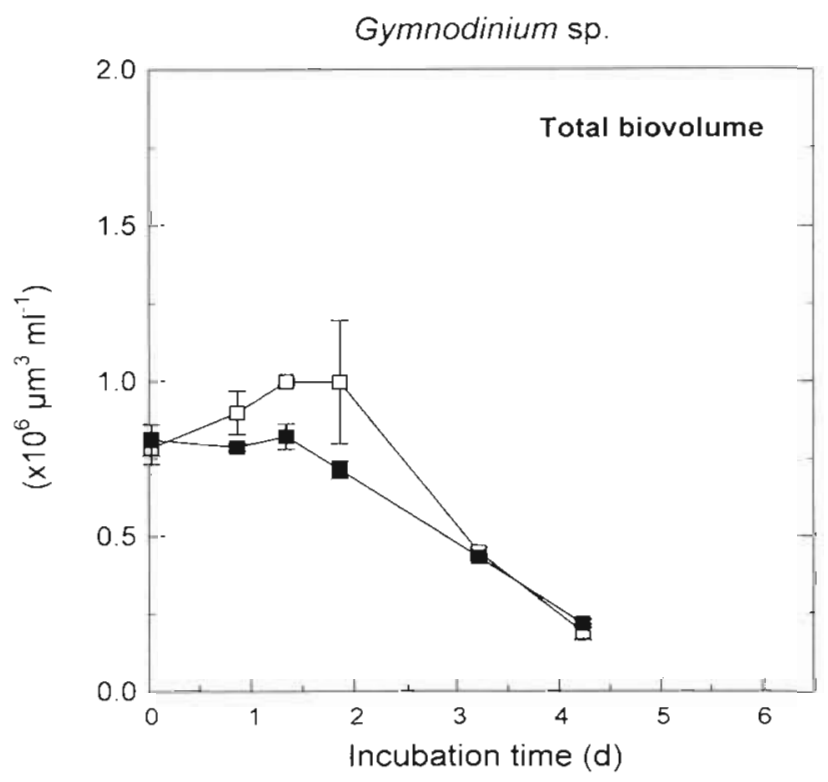

Fig. 5. Development in total biovolume of starved Gymnodinium sp. populations in triplicate cultures in light and in darkness. Data from Fig. 4, symbols as in Fig. 4 
Table 2. Growth rates $(\mu)$, per capita ingestion rates $(U)$, cell volume, estimated carbon content and gross growth efficiency (GGE) for Gymnodinium 'gracilentum' and Gymnodinium sp. at 2 different light intensities. SE in parentheses $(n=3)$

\begin{tabular}{|c|c|c|c|c|c|c|}
\hline Species & $\begin{array}{l}\text { Light intensity } \\
\left(\mu \mathrm{E} \mathrm{m} \mathrm{m}^{-2} \mathrm{~s}^{-1}\right)\end{array}$ & $\begin{array}{c}\mu \\
\left(d^{-1}\right)\end{array}$ & $\begin{array}{c}U \\
\left(R . \text { salina } \mathrm{d}^{-1}\right)\end{array}$ & $\begin{array}{l}\text { Cell volume } \\
\qquad\left(\mu^{3}\right)\end{array}$ & $\begin{array}{c}\mathrm{C} \text { content }{ }^{\mathrm{a}} \\
\left(\mathrm{pg} \mathrm{C} \text { cell }^{-1}\right\}\end{array}$ & $\begin{array}{c}G G E^{b} \\
(\%)\end{array}$ \\
\hline G. 'gracilentum' & $\begin{array}{r}6 \\
90\end{array}$ & $\begin{array}{l}0.31(0.03) \\
1.19(0.01)\end{array}$ & $\begin{array}{l}0.8(0.1) \\
2.8(0.1)\end{array}$ & $\begin{array}{l}400 \\
415\end{array}$ & $\begin{array}{l}62.1 \\
64.2\end{array}$ & $\begin{array}{l}59 \\
64\end{array}$ \\
\hline Gymnodinium sp. & $\begin{array}{r}6 \\
90\end{array}$ & $\begin{array}{l}0.81(0.09) \\
1.25(0.13)\end{array}$ & $\begin{array}{l}2.5(0.6) \\
4.1(0.8)\end{array}$ & $\begin{array}{l}261 \\
373\end{array}$ & $\begin{array}{l}42.9 \\
58.5\end{array}$ & $\begin{array}{l}32 \\
41\end{array}$ \\
\hline
\end{tabular}

\section{DISCUSSION}

This study demonstrates that Gymnodinium 'gracilentum' exhibits a mixotrophic growth strategy using chloroplasts sequestered from algal prey for performing its 'own' photosynthesis. The phagocytotic origin of the chloroplasts of $G$. 'gracilentum' is proven by the cell's need for algal food in order not to lose the chloroplasts. That the kleptochloroplasts are photosynthetically active can be concluded from the measured ${ }^{14} \mathrm{C}$ uptake (Table 1) and from the fact that starved $G$. 'gracilentum' cells survive longer in the light than in the dark (Figs. 2 \& 3). However, the kleptochloroplasts are photosynthetically beneficial for the dinoflagellate host for only $\sim 2 \mathrm{~d}$, whereupon they are digested and/or eliminated through cell division. The cell-specific photosynthetic rate of $G$. 'gracilentum' is lower than that of Rhodomonas salina, even though each $G$. 'gracilentum' cell contains 4 to 8 (or rather: 2 to 4 two-lobed) chloroplasts whereas $R$. salina cells contain only 1 large, twolobed chloroplast. The photosynthetic efficiency of the chloroplasts thus decreases when they are separated from their original host cell and kept as kleptochloroplasts (for discussion, see Stoecker et al. 1988).

Gymnodinium 'gracilentum' exhibits higher GGE than the strictly heterotrophic control organism Gymnodinium $\mathrm{sp}$. This might reflect differences in the efficiency of the 2 species at converting prey biomass into their own biomass, but, according to the above-mentioned hypothesis, it is plausible that GGE of G. 'gracilentum' is overestimated due to photosynthetic carbon fixation. Indeed, a GGE of 59 to $64 \%$ (Table 2) exceeds the upper end of the range of GGEs typically found for heterotrophic aerobic flagellates $(20$ to $50 \%$; Caron \& Goldman 1990). When interpreting the calculated GGEs, one should remember, however, that cellular $C$ content was estimated from cell volume and due to the variation of, particularly, the prey volume, these figures may be subject to error.

The increased growth rate of Gymnodinium 'gracilentum' at high light intensity is accompanied by a cor- responding increased ingestion rate, i.e. there is no evident effect of light on GGE. It seems, therefore, that photosynthesis does not contribute to growth when food is plentiful. Perhaps, G. 'gracilentum' is not C limited in the food replete cultures, but rather limited by other factors, e.g. nutrients. Since there is no evidence that chloroplast-retaining dinoflagellates are capable of taking up dissolved inorganic nitrogen or phosphorus, it is likely that kleptochloroplast photosynthesis is an advantage only by supplying organic carbon for covering respiratory needs during periods of unfavourable food conditions. More studies must be undertaken in order to understand fully the importance of photosynthesis under food replete conditions.

Gymnodinium sp. was included in this study as a representative of a strictly heterotrophic dinoflagellate and it was expected that its metabolism would not be influenced by light conditions. In fact, Gymnodinium $\mathrm{sp}$. was affected less by light conditions than $G$. 'gracilentum', but nevertheless, $\mu, U$ and $G G E$ were actually enhanced by higher light intensity (Table 2) even though food concentrations were above the saturation concentration throughout the experiment. This could be due to a dependence of the nutritional value of the prey on light intensity, but it must also be considered that even though the ${ }^{14} \mathrm{C}$-based photosynthesis experiment yielded negative results for Gymnodinium sp., one cannot exclude the possibility that food vacuoles containing phototrophic prey may photosynthesize for a short while until they become digested. Such a potential extreme short-term photosynthetic activity would not have been detected in this study, since Gymnodinium sp. had to be starved for $48 \mathrm{~h}$ in order to eliminate all prey cells. More sensitive methods for detecting photosynthesis (e.g. microautoradiography; Carman 1993) are needed to elucidate this. A third possibility is that light has a direct positive influence on digestion and growth. This is not improbable, considering that it is well established that dissolved organic matter is photochemically degradable (reviewed by Moran \& Zepp 1997) and that light, thus, has an 
indirect positive effect on bacterial production through the production of labile substrate (Lindell et al. 1996. Jørgensen et al. 1998). It needs to be studied whether such a photodegradation can occur even of particulate organic matter inside food vacuoles of heterotrophic protists and thereby enhance digestion. Although yet speculative, this would explain the beneficial effect of increased light intensity on growth of the heterotrophic Gymnodinium sp.

The ability to use ingested and retained chloroplasts for photosynthesis has been observed in many metazoa (e.g. Trench 1975) as well as in protists. Among protists, the phenomenon exists in marine ciliates, e.g. Prorodon sp. (Blackbourn et al. 1973), Laboea strobila (Jonsson 1987, Stoecker et aI. 1988) and Strombidium spp. (Blackbourn et al. 1973, Jonsson 1987, Stoecker \& Michaels 1991), and has also been found in foraminifera (Lopez 1979) and heliozod (Patterson \& Dürrschmidt 1987). The phenomenon is so far known for only a few dinoflagellate species, but many dinoflagellates belonging to the Gymnodinium/Gyrodinium species complex possess variable numbers of chloroplasts which are of uncertain origin, but which resemble the kleptochloroplasts of G. 'gracilentum' (e.g. Hansen \& Larsen 1992, Larsen 1994, 1996). It is therefore probable that chloroplast retention among dinoflagellates is much more widespread than so far perceived.

The plastid retention time for Gymnodinium 'gracilentum', i.e. the period of time for which the kleptochloroplasts remain functional, is relatively short (1 to $2 \mathrm{~d}$ ). In contrast, the dinoflagellate $G$. acidotum appears to have a plastid retention time of up to $14 \mathrm{~d}$ (Fields \& Rhodes 1991). Among chloroplast-retaining ciliates, different plastid retention times and different degrees of dependence on kleptochloroplasts have been found (Jonsson 1987. Stoecker \& Silver 1987), and it now seems that this variability applies to dinoflagellates as well. As a consequence, it is not possible to determine a general importance of kleptochloroplasts for the growth of plastid-retaining dinoflagellates. In order to understand the ecology of these organisms and their possible role in their natural habitats, it is therefore necessary to gain considerably more knowledge about the physiology of individual species.

Acknowledgements. This paper constitutes part of the requirements for my Ph.D. degree. I am grateful to my supervisors Prof. Tom Fenchel and Dr Per Juel Hansen for valuable criticism throughout the work. The photomicrographs were produced during a visit to Horn Point Laboratory, University of Maryland, MD, USA and I thank Prof. Diane K. Stoecker for giving me the opportunity to perform this part of the work. Thanks are also due to Birgit Lisager Brander and Michael Axelsen for photographic and technical assistance. The study was supported by a Ph.D. grant from The University of ppenhagen.

\section{LITERATURE CITED}

Blackbourn DJ, Taylor FJR, Blackbourn J (1973) Foreign organelle retention by ciliates. J. Protozool 20:286-288

Burkholder JM, Glasgow HB Jr (1995) Interactions of a toxic estuarine dinoflagellate with microbial predators and prey. Arch Protistenkd 145:177-188

Burkholder JM, Glasgow HB Jr, Hobbs CW (1995) Fish kills linked to a toxic ambush-predator dinoflagellate: distribution and environmental conditions. Mar Ecol Prog Ser 124: $43-61$

Campbell PH (1973) Studies on brackish water phytoplankton. University of North Carolina Sea Grant Program, University of North Carolina, Chapel Hill

Carman KR (1993) Microautoradiographic detection of microbial activity. In: Kemp PF, Sherr BF, Sherr EB, Cole JJ (eds) Handbook of methods in aquatic microbial ecology. Lewis Publishers, Boca Raton, p 397-404

Caron DA, Goldman JC (1990) Protozoan mutrient regeneration. In: Capriulo GM (ed) Ecology of manne protozoa. Oxford University Press, New York, p 283-306

Fenchel I (1982a) Ecology of heterotrophic microflagellates II. Bioenergetics and growth. Mar Ecol Prog Ser 8:225-231

Fenchel T (1982b) Ecology of heterotrophic microflagellates III. Adaptations to heterogeneous environments. Mar Ecol Prog Ser 9:25-33

Fields SD, Rhodes RG (1991) Ingestion and retention of Chroomonas spp. (Cryptophyceae) by Gymnodinium acidotum (Dinophyceae). J Phycol 27:525-529

Hansen G, Larsen J (1992) Dinoflagellater i danske farvande. In: Thomsen HA (ed) Plankton i de indre danske farvande. Havforskning fra Miljøstyrelsen, nir. 11. The Danish Environmental Protection Agency, Copenhagen, p 45-155

Hansen PJ (1989) The red tide dinoflagellate Alexandrium tamarense: effects on behaviour and growth of a tintinnid ciliate. Mar Ecol Prog Ser 53:105-116

Hansen PJ, Nielsen TG (1997) Mixotrophic feeding of Fragilidium subglobosum (Dinophyceae) on three species of Ceratium: effects of prey concentration, prey species and light intensity. Mar Ecol Prog Ser 147:187-196

Horiguchi T, Pienaar RN (1992) Amphidinium latum Lebour (Dinophyceae), a sand-dwelling dinoflagellate feeding on cryptomonads. Jpn J Phycol 40:353-363

Jakobsen HH, Hansen PJ (1997) Prey size selection, grazing and growth response of the small heterotrophic dinoflagellate Gymnodinium sp. and the ciliate Balanion comatum - a comparative study. Mar Ecol Prog Ser 158:75-86

Jonsson PR (1987) Photosynthetic assimilation of inorganic carbon in marine oligotrich ciliates (Ciliophora, Oligotrichina). Mar Microb Food Webs 2:55-68

Jørgensen NOG, Tranvik L, Edling H, Granéli HW, Lindell M (1998) Effects of sunlight on occurrence and bacterial turnover of specific carbon and nitrogen compounds in lake water. FEMS Microb Ecol 25:217-227

Larsen J (1988) An ultrastructural study of Amphidinium poecilochroum (Dinophyceae), a phagotrophic dinoflagellate feeding on small species of cryptophytes. Phycologia 27 : $366-377$

Larsen J (1994) Unarmoured dinoflagellates from Australian waters I. The genus Gymnodinium (Gymnodiniales, Dinophyceae). Phycologia 33:24-33

Larsen J (1996) Unarmoured dinoflagellates from Australian waters II. The genus Gyrodinium (Gymnodiniales, Dinophyceae). Phycologia 35:342-349

Lindell MJ, Granéli HW, Tranvik LJ (1996) Effects of sunjight on bacterial growth in lakes of different humic content. Aquat Microb Ecol 11:135-141 
Lopez E (1979) Algal chloroplasts in the protoplasm of three species of benthic foraminifera: taxonomic affinity, viability and persistence. Mar Biol 53:201-211

Marin V, Huntley ME, Frost B (1986) Measuring feeding rates of pelagic herbivores: analysis of experimental design and methods. Mar Biol 93:49-58

Moran MA, Zepp RG (1997) Role of photoreactions in the formation of biologically labile compounds from dissolved organic matter. Limnol Oceanogr 42:1307-1316

Parsons TR, Maita Y, Lalli CM (1984) A manual of chemical and biological methods for seawater analysis. Pergamon Press, Oxford

Patterson DJ, Dürsschmidt M (1987) Selective retention of chloroplasts by algivorous heliozoa: fortuitous chloroplast symbiosis? Eur J Protistol 23:51-55

Popovský J, Pfiester LA (1990) Dinophyceae (Dinoflagellida). In: Ettl H, Gerloff J, Heynig H, Mollenhauer D (eds) Süßwasserflora von Mitteleuropa. Gustav Fischer Verlag, Jena, p 1-272

Schnepf E, Elbrächter M (1988) Cryptophycean-like double membrane-bound chloroplasts in the dinoflagellate, Dinophysis Ehrenb.: evolutionary, phylogenetic and toxicological implications. Bot Acta 101:196-203

Schnepf E, Elbrächter $M$ (1992) Nutritional strategies in dinoflagellates. A review with emphasis on cell biological aspects. Eur J Protistol 28:3-24

Schnepf E, Meier R, Drebes G (1988) Stability and deforma-

Editorial responsibility: Tom Fenchel,

Helsinger, Denmark tion of diatom chloroplasts during food uptake of the parasitic dinoflagellate, Paulsenella (Dinophyta). Phycologia 27:283-290

Schnepf E, Winter S, Mollenhauer D (1989) Gymnodinium aeruginosum (Dinophyta): a blue-green dinoflagellate with a vestigial, anucleate, cryptophycean endosymbiont. Pl Syst Evol 164:75-91

Skovgaard A (1996) Mixotrophy in Fragihdium subglobosum (Dinophyceae): growth and grazing responses as functions of light intensity. Mar Ecol Prog Ser 143:247-253

Stoecker DK, Michaels AE (1991) Respiration, photosynthesis and carbon metabolism in planktonic ciliates. Mar Biol 108:441-447

Stoecker DK, Silver MW (1987) Chloroplast retention by marine planktonic ciliates. In: Lee JJ, Fredrick JF (eds) Endocy tobiology llI. Ann NY Acad Sci 503:562-565

Stoecker DK, Silver MW, Michaels AE, Davis LH (1988) Obligate mixotrophy in Laboea strobila, a ciliate which retains chloroplasts. Mar Biol 99:415-423

Strathmann RR (1967) Estimating the organic carbon content of phytoplankton from cell volume or plasma volume. Limnol Oceanogr 12:411-418

Trench RK (1975) Of 'leaves that crawl': functional chloroplasts in animal cells. Soc Exp Biol 29:229-265

Wilcox LW, Wedemayer GJ (1985) Dinoflagellate with bluegreen chloroplasts derived from an endosymbiotic eucaryote. Science 227:192-194

Submitted: February 6, 1998; Accepted: April 20, 1998

Proofs received from author(s): July 24, 1998 